Kharchenko Viktoriya,

Ph.D. in Economics, Associate Professor of Donetsk National Technical University

\title{
INNOVATIVE ACTIVITY OF AN ENTERPRISE IN THE PROCESS OF DEVELOPM ENT
}

The aim of innovative activity is the search of mechanisms that ensure the innovative process at an industrial enterprise for quick responds to market challenges during the development. There has been suggested the system of innovative activity management that includes groups and types of strategies of innovative activity management, types of innovations, conditions of strategies realization. Such scientific and methodological approach to the formation of the system of innovative activity management ensures the complex managerial decision-making and higher efficiency of strategic management of an industrial enterprise development.

Key words: innovative activity; enterprise; management of innovative activity; strategy; types of innovations; development.

(C) Харченко Вікторія

Надійшла до редакції 27.11.2015

удк 351.755

ШАБАЛІНА ЛЮДМИЛА,

кандидат економічних наук, доиент

Донецького начіонального технічного університету

КАПКО АННА,

Донецьький національний технічний університет

\section{МІЖНАРОДНІ АСПЕКТИ РЕГУЛЮВАННЯ ПОТОКІВ БІЖЕНЦІВ}

\begin{abstract}
У статті було проаналізовано світові міграційні потоки за останні 25 років. Розглянуто міграційні потоки за географічною, гендерною та освітньою ознаками. Визначено основні проблеми біженців, що полягають у працевлаштуванні та отриманні офіційного статусу біженця. Розглянуто нелегальну міграцію, а також пов'язані 3 нею проблеми. Проаналізовано основні маршрути біженців. У зв'язку з цим визначено основні країни - експортери та імпортери біженців. Проаналізовано основні заходи, що має намір ужити Єврокомісія для регулювання міграційної кризи, яка склалась у світі.
\end{abstract}

Ключові слова: міграційні потоки; іммігранти; біженці; статус біженця; притулок; Дублінська угода; реадмісія.

Постановка проблеми. Проблема біженців та дотримання їхніх прав гостро стоїть перед світовою спільнотою, оскільки вона пов'язана з внутрішнім становищем цілого ряду країн, відповідальністю урядів, діяльністю міжнародних організацій, неурядових фондів і навіть окремих громадян у всьому світі. Міжнародна організація 3 міграції (МОМ) оцінила загальну чисельність мігрантів у світі в 178 млн ос. у 2000 році, із яких 14,5 млн осіб - біженці. Станом на 2015 рік загальна кількість мігрантів - 232 млн осіб, із яких більше 50 млн осіб склали біженці $[1,2]$. 3 них приблизно половина проживає в 10 високоурбанізованих країнах із високим рівнем доходу - Австралії, Великобританії, Канаді, США, Франції, Німеччині, Росії та Саудівській Аравії. Очікується, що до 2050 року кількість міжнародних мігрантів досягне 405 млн осіб, що, відповідно, спричинить ряд негативних наслідків у світі [1]. Розміри міграційних потоків, які збільшуються з року в рік, призвели до необхідності міжнародного регулювання цьо- го процесу. Виходячи з обставин, що склалися, стає необхідним проаналізувати особливості сучасних міграційних потоків та ефективні заходи щодо регулювання потоків біженців.

Ступінь вивченості. Актуальність порушених питань пояснює інтерес з боку вчених та фахівців-практиків. Так, загальні питання міграції були розглянуті в працях Д.-К. Нгуєна, С. Зуммерматтер, Н. М. Аітова, О. К. Дадаєва. Підходи до вирішення проблем міграційної кризи відображені в працях Г. Дудіної, О. М. Каменського, Г. О. Баришевої, Г. І. Тюменцева, А. Е. Вовка та ін. Проблему біженців вивчали Є. Г. Белькова, А. М. Ібрагімов, 3. Ф. Іранпур, С. Є. Селезньова та ін. Значний внесок у вирішення проблеми регулювання потоків біженців зробили А. Гаганов, М. Д. Габова, Т. Мехтієв, В. Н. Стегній, К. А. Антипов, Й. Луїджі та ін.

Мета роботи - проаналізувати особливості сучасних міграційних потоків.

Об'єкт дослідження - потоки біженців у світі. 
Предмет дослідження - заходи щодо регулювання потоків біженців.

Виклад основного матеріалу. На початок 1990-х років, за даними МОМ, у світі налічувалося близько 156 млн мігрантів, що становило трохи менше 3 \% усього населення планети, із них біженців налічувалося
14 млн осіб. Протягом останніх 25 років спостерігалася тенденція до збільшення кількості мігрантів (рис. 1). Так, у 2015 р. у світі налічується понад 200 млн мігрантів, які складають більше 3 \% населення планети (рис. 2). Окремо прогнозне значення кількості біженців до кінця 2015 року становить близько 60 млн осіб у світі.

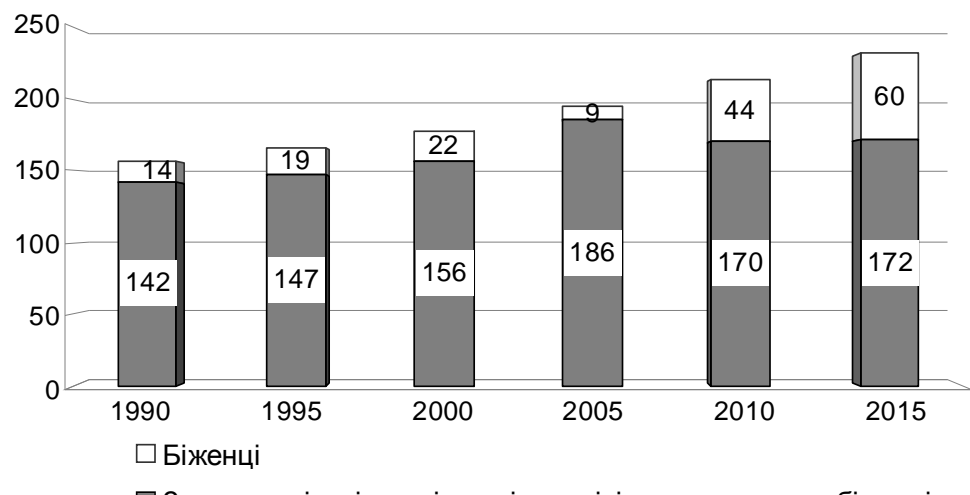

$\square$ Загальна кількість мігрантів у світі, не включаючи біженців

Рис. 1. Кількість мігрантів у світі (млн осіб) [3].
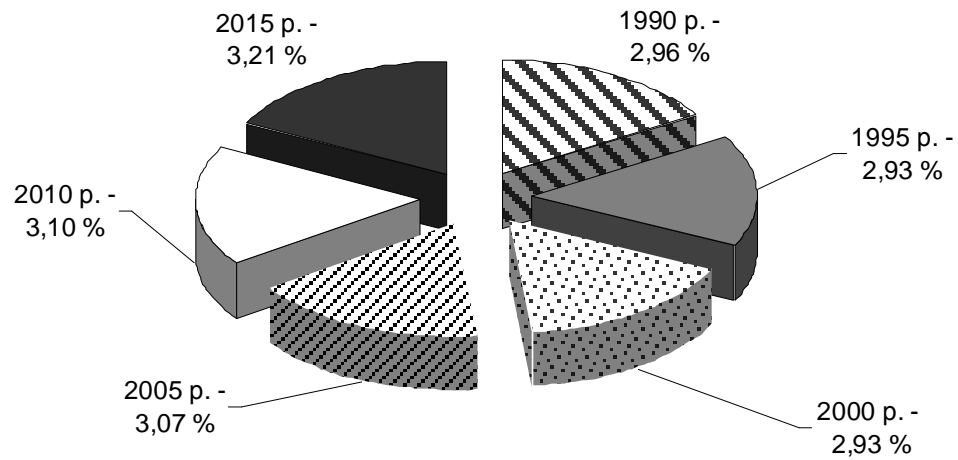

Рис. 2. Частка мігрантів у загальній кількості населення [4].

Зростання кількості мігрантів демонструє тенденцію до збільшення, незважаючи на те, що багато країн уживають заходів щодо обмеження міграції. За 25 років кількість мігрантів зросла трохи менше, ніж на 100 млн осіб, а кількість біженців - на 50 млн осіб.

Якщо подивитися на частку мігрантів у світі по відношенню до кількості населення планети, то можна так само відзначити тенденцію збільшення кількості мігрантів. Так, станом на 1990 рік кількість мігрантів становила 2,96 \% населення планети, тоді як уже в 2015 році - 3,21\%. Кількість біженців склала в 1990 році - 0,3 \% населення, а у 2015 - 0,8 \%, при цьому слід урахувати, що кількість населення планети теж зросла значною мірою.

Біженців усе більше приваблюють країни з найвищими темпами економічного зростання (рис. 3). Так, за даними Управління Верховного комісара $\mathrm{OOH}$ у справах біженців (УВКБ), 86 \% усіх біженців по всьому світу проживають у країнах, що розвиваються. До таких країн належать Східна Азія, Бразилія, Західна Індія і Південна Африка. Однак при цьому, якщо більшість мігрантів прагне до Південної Африки, то значну кількість біженців (30 \%) - складають мігранти із Західної Африки з причини високого рівня бідності. Так, уважається за

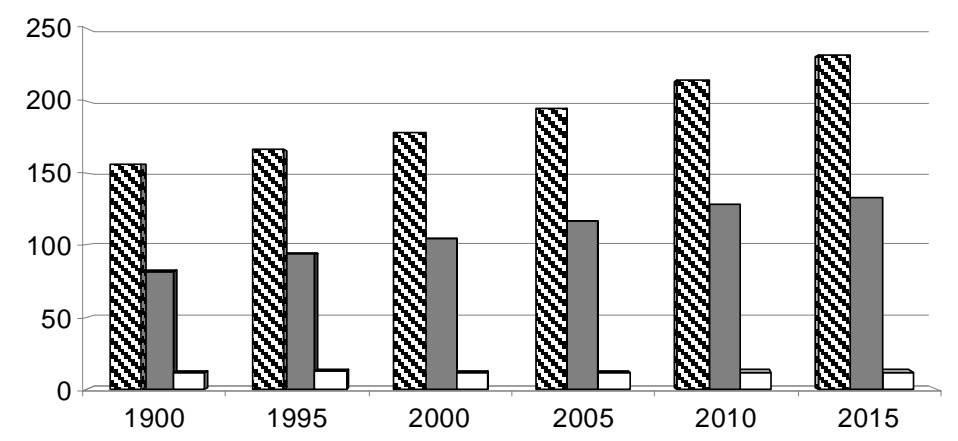

Більш розвинені регіони

$\square$ Менш розвинені регіони

$\square$ Найменш розвинені країни

Рис. 3. Кількість мігрантів по регіонах (млн осіб) [5]. 
доцільне сприяти економічному розвитку країн Західної Африки, а саме: розвивати сільськогосподарські райони, при цьому цінова політика та стимулювання інвестиційної діяльності дрібних фермерів повинні підкріплюватися інституційними та структурними реформами. Такий підхід дозволить вирішити продовольчу проблему не тільки країн Африки, а й промислово розвинених країн. При цьому важливо посилити контроль за екологічною безпекою й підвищенням ролі соціального захисту населення, а також розробити заходи щодо запобігання розоренню земель. Доцільно відновити потік фінансових надходжень із державних і при- ватних джерел у країни Африки через надання підприємцям різних пільг, таких як "пільгові канікули", пільгові кредити тощо.

Експерти МОМ відзначають, що ще однією особливістю міграції $€$ те, що майже половина всіх мігрантів - жінки репродуктивного віку, для яких міграція $€$ засобом розширення своїх можливостей, оскільки в них з'являється можливість на отримання громадянства в країні прибуття через укладення шлюбу з іноземним суб'єктом або через народження дитини, яка буде вважатися громадянином країни прибуття [6, с. 121] (рис. 4).

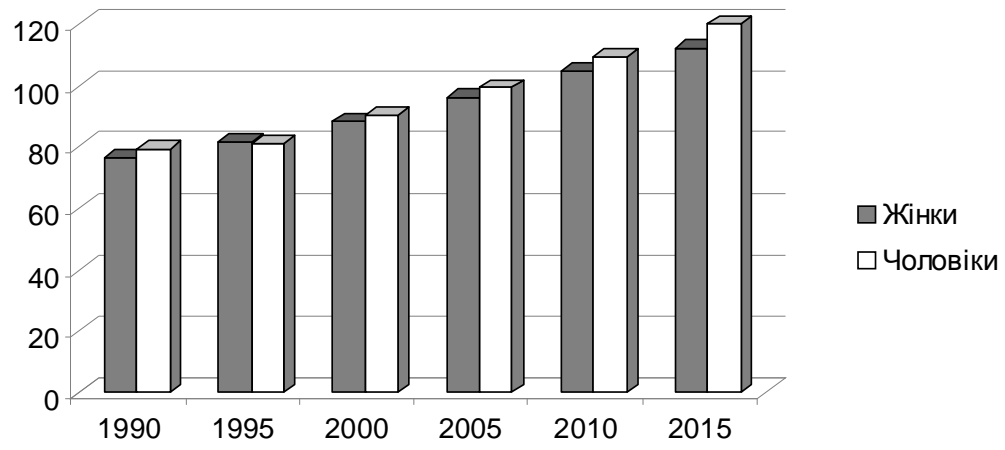

Рис. 4. Характеристика мігрантів за гендерною ознакою [3].

При цьому варто зауважити, що більша кількість мігрантів має середню та середню спеціальну освіту, тоді як вищу освіту мають лише $13 \%$ мігрантів (рис. 5). Необхідно звернути увагу на проблему неосвіченості більшої кількості мігрантів, а відповідно й біженців.
Доцільно передбачити можливість вивчення мови країни мігрантами, а також отримання середньої спеціальної освіти, що дозволить мігрантам затриматися в країні прибуття, освоїти професію й поповнити чисельність робочої сили країни прибуття.

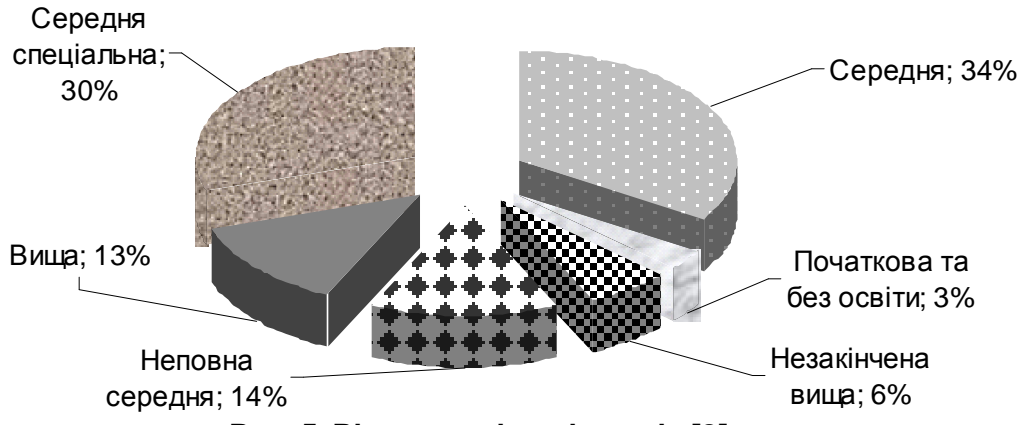

Рис. 5. Рівень освіти мігрантів [8].

Основні проблеми мігрантів та біженців у сучасному світі полягають у працевлаштуванні та отриманні офіційного статусу. Так, наприклад, Туреччина відмовила більшій частині біженців із Сирії в працевлаштуванні. У зв'язку із цим доцільно розробити єдиний закон про визнання біженців, їх офріційне працевлаштування, що зберігає їхні права та надасть рівні можливості з громадянами країни прибуття. Різні країни керуються власними законами про правове становище іноземних громадян. Тому варто, щоб усі країни ратифікували розроблений нормативний документ, оскільки було відмічено, що держави з низьким рівнем розвитку негативно сприймають мігрантів зі статусом "біженець", що створює ряд труднощів при працевлаштуванні. Цей захід дозволить біженцям затриматися в країні прибуття та сплачувати податки, що позитивно позначиться на економіці держави.

На цьому етапі правове поле біженців регулюється конвенцією про права біженців, прийнятій у 1951 році на Женевській конференції представниками Генеральної Асамблеї ООН, яку ратифікували 144 країни світу.
Уважається, що держава повинна гарантувати біженцям право на працевлаштування, вільний найм, а також отримання державної та соціальної допомоги. Однак при цьому, наприклад, в Іспанії, яка також ратифікувала конвенцію, на гарну посаду воліють брати корінних жителів, тоді як мігранти влаштовуються на найважчу й малооплачувану роботу [9].

Експерти пропонують розробити закон про біженців, що передбачає фінансування Міністерства праці та соціальної політики, Міністерства охорони здоров'я, Міністерства освіти країни прибуття. На їхню думку, необхідно розробити програму допомоги біженцям, яка регулюватиме питання переселення, транспортування, обробки, прийому й витрат переселення біженців [15].

На сучасному етапі розвитку значно збільшилися потоки нелегальної, вимушеної міграції морським шляхами, що стало світовою проблемою. У 2015 році склалася ситуація міграційної кризи на південних і південно-східних кордонах Європи. Ніколи ще потоки біженців, які перетинають кордон морем, не були настільки ве- 
ликими. Станом на вересень 2015 року через Середземне море до Європи добралося майже 350 тис. осіб, що в порівнянні з аналогічним періодом часу у 2014 році склало приріст у $60 \%$ (рис. 6).
Перш все, це зростання склали вимушені мігранти, які покинули регіони з нестабільною військово-політичною обстановкою, зокрема Афрганістан, Сирію й Еритрею (рис. 7).

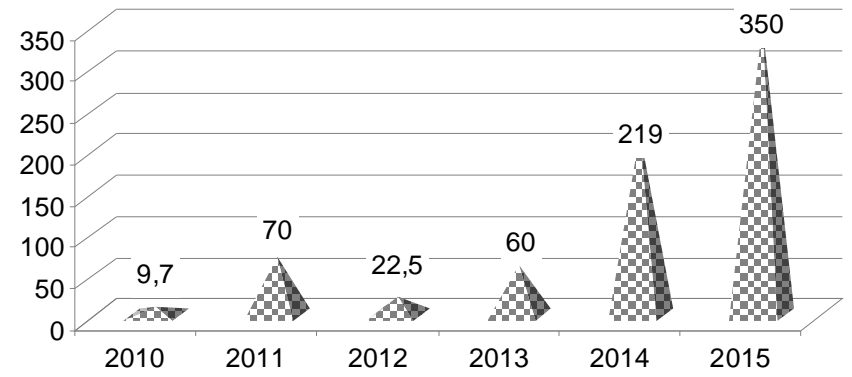

Рис. 6. Біженці й нелегальні мігранти, які прибули в Європу морем, тис. осіб [7].

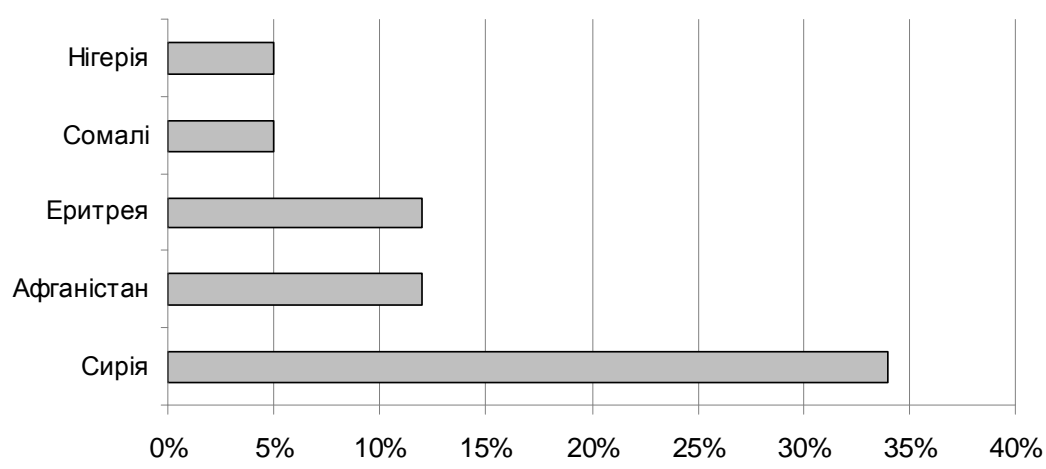

Рис. 7. Топ-5 країн, з яких прибуває найбільша кількість мігрантів морем, 2014 \% [7].

За 2014 рік у Європі було зареєстровано більше 660 тис. біженців, які подали офріційні клопотання про надання притулку (рис. 8). Списки країн-лідерів, жителі яких найчастіше подають прохання про притулок, постійно оновлюються залежно від країни прийому й від сезону. Наприклад, в Італію через Середземне море масово емігрують вихідці з Нігерії, Малі та Гамбії, в
Угорщину - жителі Косова, Афрганістану та Сирії. Найбільш кризова ситуація - у вихідців із Сирії: за даними $\mathrm{OOH}$, з 2011 року країну покинули 4 млн громадян. У цілому в топ-10 стабільно входять переселенці з країн Азії - Сирії, Афрганістану, Пакистану та Іраку, Африки Еритреї, Нігерії, Гамбії та Малі, а також економічні біженці з Косова та Сербії [3].

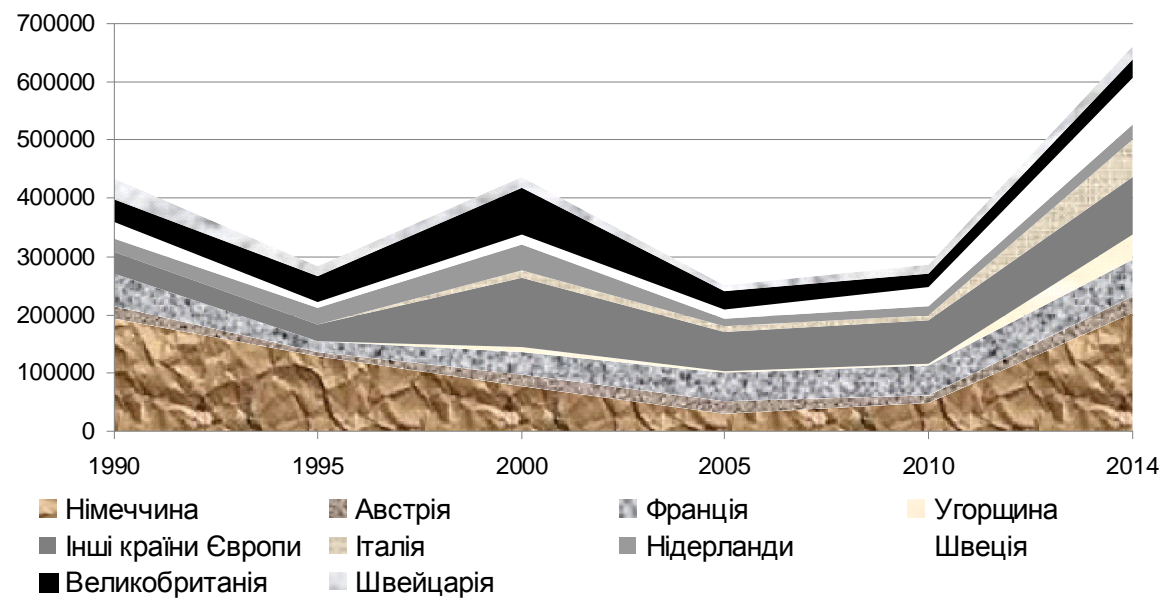

Рис. 8. Кількість клопотань про надання притулку [10].

Найпопулярнішим маршрутом серед біженців, які прагнуть дістатися Європи, став шлях через Балкани (рис. 9). За останні місяці 2015 року морські кордони Європи стали для нелегальної міграції багато в чому непроникними. Тому Балканський маршрут, який використовують понад 60 \% біженців залишається єдиною реальною альтернативою, навіть незважаючи на те, що ЄС продовжує вкладати значні кошти в зміцнення прикордонного режиму на своїх сухопутних кордонах [10].
Європейські країни при вирішенні проблеми біженців спираються на умови Дублінської угоди - документа, що регламентує відносини між країнами ЄС у процедурі надання притулку. Основний принцип Дублінської угоди полягає в тому, що тільки одна країна відповідальна за розгляд запиту про притулок. Яка саме, визначається на основі таких критеріїв [11]:

- відповідальною $€$ країна, де партнер або неповнолітня дитина вже визнані біженцем; 

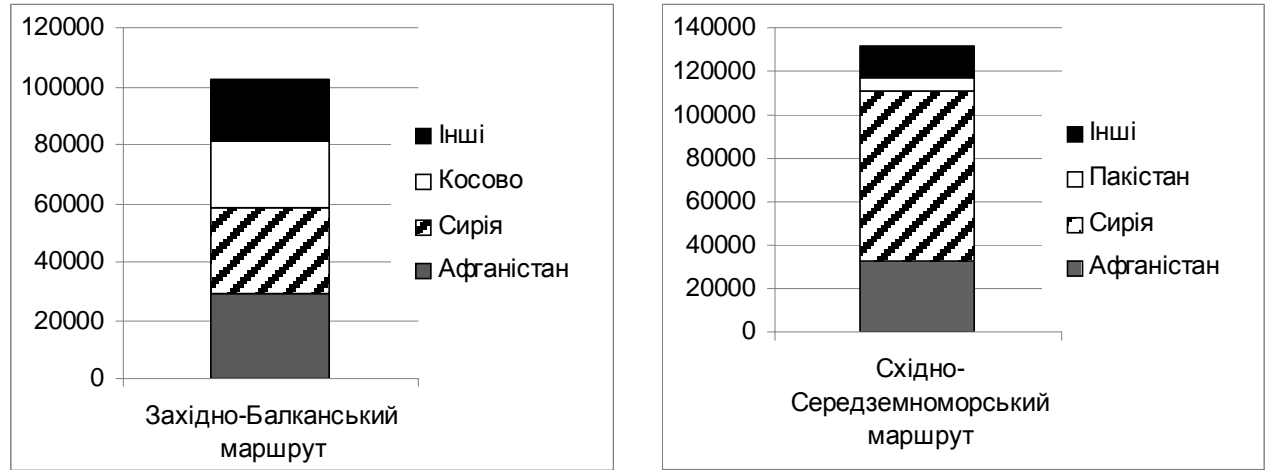

Рис. 9. Основні маршрути потоків мігрантів у Європу [7].

- відповідальною є перша країна, яка видала візу або посвідку на проживання;

- у разі безвізового в'їзду відповідальною є перша країна, кордон якої мігрант перетнув і мав реальну можливість звернутися до влади;

- та країна, де раніше вже вимагався притулок.

Дублінську угоду підписали всі країни Європейського Союзу, плюс Ісландія, Норвегія, Швейцарія і Ліхтенштейн.

Однак нинішня практика, коли статус біженця потрібно отримувати там, куди мігрант прибув спочатку, себе не виправдала - проти налаштовані прикордонні країни - Італія, Греція, Іспанія та Угорщина. Тому доцільно переглянути положення Дублінської угоди, зміцнити охорону кордонів ЄС й укласти список "безпечних країн" для біженців. Це торкнеться, найшвид- ше, Балканських держав, звідки до ЄС направляються тисячі економічних біженців [14]. Спільна політика в цьому питанні буде гарантувати те, що біженці розподіляться по країнах ЄС рівномірно і не будуть намагатися потрапити в певні країни.

Різні країни по-різному підходять до проблеми регулювання потоків біженців. Німеччина, наприклад, відкрила свої кордони і звернулася до інших країн із закликом проявити солідарність, також тимчасово припинила процедуру реадмісії біженців із Сирії в країни, які, згідно з Дублінською процедурою, були формально країнами їх першого прибуття в ЄС. Тим самим, поставивши Дублінську угоду під питання (відповідно до неї біженцями мали б займатися Італія та Греція). Хоча у 2014 році Німеччина перебувала в Європі на першому місці за кількістю висланих біженців (рис. 10).

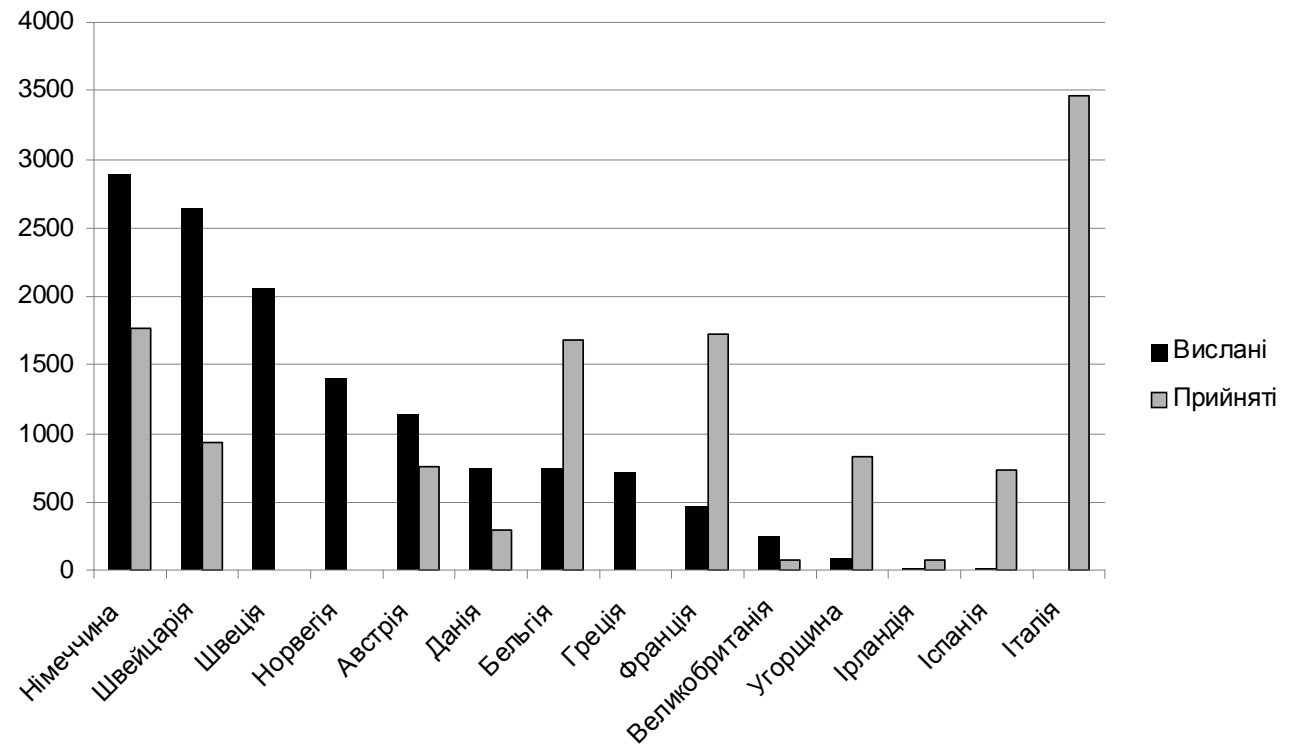

Рис. 10. Біженці в Європі, вислані у 2014 році в рамках Дублінської угоди до країни "першого прибуття" [13].

Східноєвропейські країни, зі свого боку, відмовляються приймати біженців, а також установлюють різні умови для їх прийняття. Угорщина, наприклад, на територію якої прибувають тисячі біженців, в останній час робила зусилля щодо повного закриття своїх кордонів. Крім того, Угорщина збирається побудувати на кордоні із Сербією стіну довжиною в 175 км, хоча саме Угорщина замикає список країн, що прийняли позитивне рішення про прийняття біженців на свою територію. Частка її позитивних рішень складає всього 9,4 \%, оскільки в цю країну в переважній більшості намагаються потрапити біженці з Косова, що офіційно вважається безпечною країною (рис. 11). Словаччина оголосила готовність приймати біженців - але тільки християнського віросповідання. Болгарія різко посилила режим прикордонного контролю, маючи намір спорудити додаткові укріплення довжиною в 130 км уздовж свого кордону з Туреччиною. Це пояснюється тим, що Болгарія і так прийняла вже велику кількість біженців і частка ї̈ позитивних рішень про прийняття біженців становить $94,1 \%$ (рис. 11 ).

У Швейцарії неурядові партії вимагають кинути армію на зміцнення прикордонного режиму [10]. Однак при цьому Швейцарія належить до країн з однією 3 найвищих квот (70,5 \%) позитивних рішень за клопотаннями про надання притулку (рис. 11). 


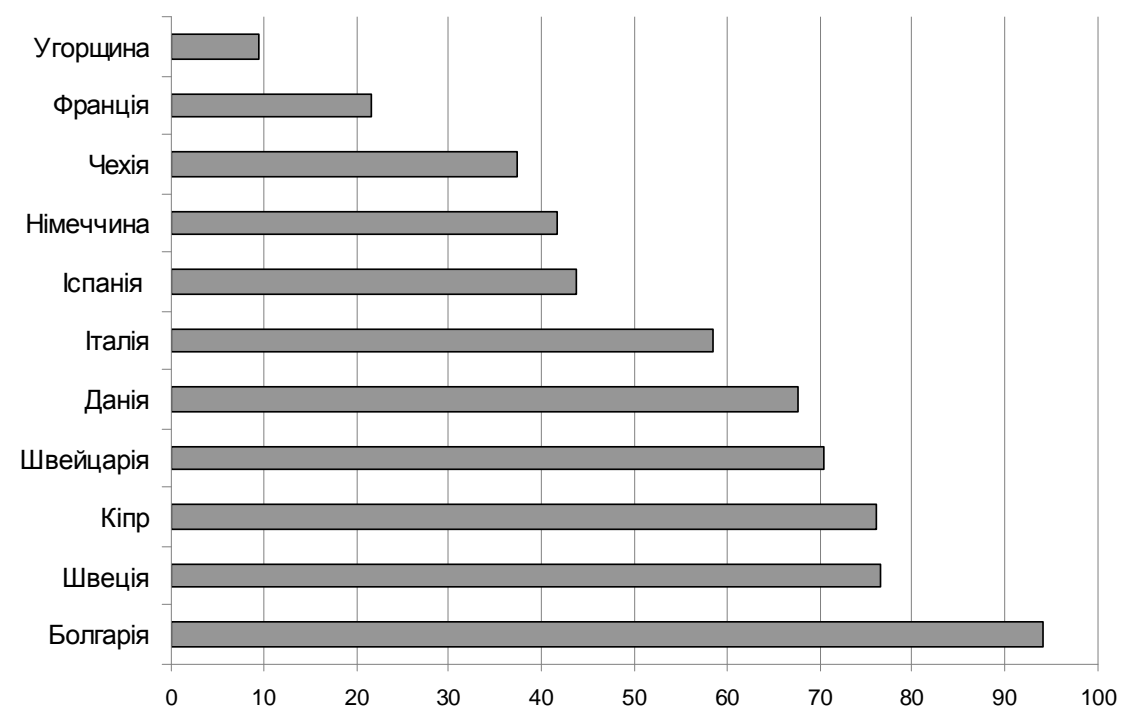

Рис. 11. Частка позитивних рішень про прийом біженців у 2014 р. (\%) [12].

Зіткнувшись із міграційною кризою, Європейський Союз активно шукає вирішення цієї проблеми, яке влаштовувало б усіх членів $€ С$, було б справедливим, адекватним і розрахованим як мінімум на середньострокову перспективу. Єврокомісія підготувала пакет нових заходів із урегулюванню міграційної кризи. Зокрема, раніше оголошені квоти на розподіл по країнах ЄС 40 тис. біженців тепер будуть збільшені ще на 120 тис. Так, Німеччині пропонують прийняти додатково 31,4 тис. біженців, Франції - 24 тис., Іспанії - майже 15 тис. Квоти також повинні розподілятися і відповідно до кількості вже прийнятих біженців. У підсумку республіки Прибалтики, що активно виступали проти системи примусового розподілу, повинні будуть прийняти значно менше біженців, ніж країни "старої Європи": Литва - додатково 800 осіб, Естонія - 400 і Латвія - 500 осіб [15].

\section{Висновки}

На основі проведеного аналізу світових міграційних потоків, були виявлені основні їхні особливості та тенденції. Виявлено, що за останні 25 років спостерігається збільшення частки мігрантів у загальній чисельності населення і частка біженців з року в рік збільшується. Розглянуто міграційні потоки за географічною, гендерною та освітньою ознаками. Визначено основні проблеми біженців, що полягають у працевлаштуванні та отриманні офріційного статусу біженця. Розглянуто основні заходи, що вживаються світовим співтовариством для регулювання потоків біженців, а також їх переваги та недоліки. На основі аналізу чинного міжнародного законодавства рекомендовано заходи щодо врегулювання міграційної кризи, що склалась у міжнародному просторі.

\section{ЛІТЕРАТУРА}

1. К 2050 году число международных мигрантов почти удвоится [Електронний ресурс] / Центр новостей ООН. - Режим доступу : http://www.un.org/russian/news/story.asp?NewsID $=14648 \#$. VISqX46pthk.

2. World Refugee Day: Global forced displacement tops 50 million for first time in post-World War II era [Електронний ресурс]
/ UNHCR. - Режим доступу : http://www.unhcr.org/53a155bc6. $\mathrm{html}$.

3. Офріційний сайт ООН [Електронний ресурс]. - Режим доступу : http://www.un.org/ru/development/migration/.

4. Офріційний сайт Всесвітнього Банку [Електронний ресурс]. - Режим доступу : http://data.worldbank.org/indicator.

5. Офіційний сайт International Organization For Migration [Електронний ресурс]. - Режим доступу : http://www.iom.int/ world-migration.

6. International Migration // IOM Publications. - 2015. - Vol. 53 (2). - $408 \mathrm{p}$.

7. Нелегальная миграция в Европу. Статистика [Електронний ресурс] // VGil Journal. - Режим доступу : http://vgil.ru/ 2015/09/13/nelegalnaya-migraciya-v-evropu-statistika/.

8. Офріційний сайт International Organization For Migration Российская Федерация [Електронний ресурс]. - Режим доступу : http://moscow.iom.int/russian/index.html.

9. Проблемы беженцев и мигрантов: все аспекты [Електронний ресурс]. - Режим доступу : http://www.migrationpatent.ru/index/razdel3/problemy-bezhencev.

10. Nguyen Duc-Quang. Six graphs to understand the migration phenomenon [Електронный ресурс] / Duc-Quang Nguyen, Stefania Summermatter. - Режим доступу : http://www.swissinfo. ch/eng/refugee-crisis_making-sense-of-migration--facts-andfigures/41560118.

11. Дублинское соглашение. Запрос убежища [Електронний ресурс]. - Режим доступу : http://azulyant.livejournal.com/ 1557.html.

12. Офріційний сайт Eurostat [Електронний ресурс]. - Peжим доступу : http://ec.europa.eu/eurostat/data/database?node _code=migr_emi1ctz.

13. Incoming 'Dublin' transfers by submitting country (PARTNER), legal provision and duration of transfer [Електронний ресурс] // Eurostat. - Режим доступу : http://appsso.eurostat. ec.europa.eu/nui/show.do.

14. Дудина Г. Откройте, миграция [Електронний ресурс] / Г. Дудина // Коммерсант. - 2015. - 09.09. - Режим доступу : http://www.kommersant.ru/doc/2806383.

15. Как решить миграционный кризис в Европе [Електронний ресурс]. - Режим доступу : http://www.imperiyanews.ru/ details/0f719891-0948-452d-b48d-d8580d8b06f1. 
Шабалина Людмила, кандидат экономических наук, доцент Донеикого национального технического университета

Капко Анна, Донеикий национальный технический университет

\section{МЕЖДУНАРОДНЫЕ АСПЕКТЫ РЕГУЛИРОВАНИЯ БЕЖЕНЦЕВ}

В статье были проанализированы мировые миграционные потоки за последние 25 лет. Рассмотрены миграционные потоки по географическому, гендерному и образовательному признаку. Определены основные проблемы беженцев, которые заключаются в трудоустройстве и получении официального статуса беженца. Рассмотрена нелегальная миграция, а также связанные с ней проблемы. Проанализированы основные маршруты беженцев и определены основные страны экспортеры и импортеры беженцев. Проанализированы основные мероприятия, которые намерена предпринять Еврокомиссия, для урегулирования сложившегося миграционного кризиса.

Ключевые слова: миграционные потоки, иммигранты, беженцы, статус беженца, убежище, Дублинское соглашение, реадмиссия.

Shabalina Liudmyla, Candidate of economic sciences, associate professor of Donetsk National Technical University

Kapko Anna,

Donetsk National Technical University

\section{INTERNATIONALASPECTSOF REFUGEES' REGULATION}

The global migration flows have been analyzed in the article over the past 25 years. There was a trend of increasing the share of migrants in total population, in which the proportion of refugees is growing from year to year. According to the forecast the number of migrants in 2050 will increase by $75 \%$ compared to 2015 Migration flows by geographical, gender and educational grounds were considered. It was noted that $64 \%$ of migrants have secondary and specialized secondary education, while only $13 \%$ have higher education. It was revealed that nearly half of all migrants are women of reproductive age. It was determined that $86 \%$ of refugees are attracted by the countries with the highest rates of economic growth, such as Asia, Brazil, Western India and South Africa. The main problem of the refugees, which are related to employment and receiving official refugee's status, were identified. It was revealed that there is a negative attitude towards migrants with the status of "refugee" in several countries, when situation connects with employment. Illegal migration, which has tendency to increase in recent years, was considered, as well as the problems which are associated with it. The main routes of refugees were analyzed. It was found that the majority of illegal immigrants had entered the country by sea. In this regard, the main countries, that export and import refugees, were identified. The disadvantages of the Dublin Agreement, which is the main legal basis that regulates relations between the countries of the EU in the asylum procedure, were considered. The main activities, that the European Commission is going to undertake to regulate existing migration crisis, were analyzed. The strengthening of border security and the increasing of the quotas for the distribution of migrants by countries of the EU, which will promote the uniform distribution of refugees by the countries, were identified among them.

Keywords: migration flows, migrants, refugees, the status of refugee, asylum, the Dublin agreement, readmission.

\section{REFERENCES}

1. By 2050, the number of international migrants almost doubled. - UN News Centre, available at: http://www.un.org/russian/news/ story. asp?NewsID=14648\#. VISqX46pthk - 24.11.15.

2. World Refugee Day: Global forced displacement tops 50 million for first time in post-World War II era. - UNHCR, available at: http:/ /www.unhcr.org/53a155bc6.html - 24.11.15.

3. UN Official website, available at: URL: http://www.un.org/ru/development/migration/ - 24.11.15

4. The official website of the World Bank, available at: http://data.worldbank.org/indicator - 24.11.15

5. The official website International Organization For Migration, available at: http://www.iom.int/world-migration - 25.11.15

6. International Migration (2015), IOM Publications, Vol.53 (2), 408 p. (eng).

7. Illegal migration to Europe. Statistics (2015), VGil Journal, available at: http://vgil.ru/2015/09/13/nelegalnaya-migraciya-v-evropustatistika.

8. The official website of Organization For Migration, Russian Federation, available at: http://moscow.iom.int/russian/index.html.

9. The problems of refugees and migrants: all aspects, available at: http://www.migration-patent.ru/index/razdel3/problemy-bezhencev.

10. Nguyen Duc-Quang, Summermatter Stefania (2015), Six graphs to understand the migration phenomenon available at: http:// www.swissinfo.ch/eng/refugee-crisis making-sense-of-migration-facts-and-figures/41560118 - 26.11.15.

11. Dublin agreement. Request of asylum (2015), available at: http://azulyant.livejournal.com/1557.html.

12. The official website of Eurostat, available at: http://ec.europa.eu/eurostat/data/database?node code=migr emi1ctz -26.11 .15$

13. Incoming "Dublin" transfers by submitting country (PARTNER), legal provision and duration of transfer (2015), Eurostat, available at: http://appsso.eurostat.ec.europa.eu/nui/show.do - 14.12.15.

14. Dudina G. (2015), Open, migration, Kommersant, 09.09, available at: http://www.kommersant.ru/doc/2806383 - 26.11 .15

15. How to solve the immigration crisis in Europe available at: http://www.imperiyanews.ru/details/0f719891-0948-452d-b48dd8580d8b06f1 - 26.11.15

(C) Шабаліна Людмила, Капко Анна

Надійшла до редакції 02.12.2015

СХІД № 8 (140) грудень 2015 p. 